DOI

\title{
ВПЛИВ ЦИТОФЛАВІНУ НА БІОЕЛЕКТРИЧНУ АКТИВНІСТЬ НЕРВОВО-М'ЯЗОВОГО КОМПЛЕКСУ В УМОВАХ ЕКСПЕРИМЕНТАЛЬНОЇ МЕНОПАУЗИ
}

\author{
๑О. Г. Родинський, С. С. Ткаченко, О. Г. Зинов'єва \\ Державний заклад «Дніпропетровська медична академія МОЗ України»
}

\begin{abstract}
РЕЗЮМЕ. Мета дослідження-експериментальне вивчення змін біоелектричної активності нервово-м'язового комплексу під впливом препарату Цитофлавін в умовах експериментальної менопаузи. Препарат вводили інтраперитонеально самицям білого щура через 120 днів після оваріогістеректомії впродовж 10 днів. Аналізували параметри збудливості нервово-м'язового комплексу та параметри викликаних відповідей при прямому та непрямому подразненні литкового м'яза. Зафіксоване достовірне $(p<0,01)$ підвищення порогу збудження литкового м'яза як при прямому, так і при непрямому подразненні на $(120,0 \pm 7,270) \%$ та $(85,71 \pm 6,15) \%$ відповідно. Також відмічається відносне зменшення кількості низькопорогових нейромоторних одиниць. Таким чином, під впливом компонентів препарату Цитофлавін відбувається нормалізація збудливості нервово-м'язового апарату, цей препарат може бути рекомендований до застосування як один з компонентів комплексного лікування та профілактики віддалених нейропатичних ускладнень ранньої менопаузи.

КЛЮчОВІ СЛОВА: хірургічна менопауза, нервово-м'язовий комплекс, цитофлавін.
\end{abstract}

Вступ. У віддалені строки хірургічної менопаузи часто виникають скарги на м'язову напругу, судоми, слабкість та втому $[4,14]$. Жіночі статеві гормони чинять модулювальний вплив на центральну та периферійну нервову систему та роблять суттєвий внесок у виникнення вищеперерахованих симптомів $[12,15]$.

У наших попередніх дослідженнях було встановлено, що під час хірургічної менопаузи відбувається підвищення збудливості нервовом'язового апарату як при прямому, так і при непрямому подразненні [10]. Значний внесок у ці зміни робить гіпоксія нервових структур та м'язів на фоні їх підвищеної чутливості до нестачі кисню через зниження нейропротективного впливу статевих стероїдів [17], порушення процесів мієлінізації [18], посилення процесів перикисного окиснення ліпідів, зниження активності $\mathrm{Na}^{+} / \mathrm{K}^{+}$-АТФази [16] та спотворення мікроструктури аксона [13].

Метою нашого дослідження було експериментальне вивчення фармакологічної активності комплексного препарату Цитофлавін, який має антиоксидантні та метаболотропні властивості, як одного з засобів корекції вищезазначених порушень.

Цитофлавін - стерильний розчин для внутрішньовенних ін'єкцій - $є$ комплексним лікарським препаратом та має високу біодоступність. Це збалансований комплекс з двох метаболітів бурштинової кислоти 1 г та рибоксину 200 мг, i двох коферментів вітамінів - рибофлавіну мононуклеотиду 2 мг (вітамін В2) та нікотинаміду 100 мг (вітамін РP) [6].

Патогенетичним обгрунтуванням використання препарату Цитофлавін $\epsilon$ те, що він стимулює дихання і енергоутворення в клітинах, покращує процеси утилізації кисню і глюкози у тканинах, відновлює активність ферментів антиоксидант- ного захисту, активує внутрішньоклітинний синтез білка, сприяє ресинтезу $\gamma$-аміномасляної кислоти в нейронах [5]. Також $є$ експериментальні дані щодо ефективності даного препарату при лікуванні діабетичної невропатії [2].

Матеріал і методи дослідження. Експерименти були проведені на 41 білому статевозрілому щурі-самиці лінії Вістар вагою 200-250 г через 120 діб [13] після тотальної оваріогістеректомії [9] з метою створення експериментальної менопаузи. Тварин було поділено на 2 групи: контрольну (27 тварин) та піддослідну (14 тварин). Щури піддослідної групи отримували інтраперитонеально розчин препарату Цитофлавін, розведений у 10 разів фізіологічним розчином хлориду натрію 0,9\%, у дозуванні 0,13 мл/100 г ваги впродовж 10 днів. Тваринам контрольної групи інтраперитонеально вводили фізіологічний розчин хлориду натрію 0,9 \% - 0,26 мл. Обидві групи тварин утримували у стандартних умовах віварію $\left(t^{\circ}(22 \pm 2)^{\circ} \mathrm{C}\right.$, світлий/ темний цикл - 12/12 год). Під загальною анестезією тіопенталом-натрію 5 мг/100 г ваги, відпрепарований на стегні сідничний нерв розміщували на біполярних електродах та подразнювали прямокутними імпульсами тривалістю 0,3 мс. Відведення потенціалу дії (ПД) від литкового м'яза, а також його пряме подразнення здійснювали за допомогою голчастих електродів, які вводили безпосередньо у м'яз [9]. Аналізували поріг, хронаксію, амплітуду ПД, латентний період (ЛП) та тривалість ПД при непрямому подразненні, а також поріг (П) та хронаксію при прямому подразненні литкового м'яза. Також вивчали динаміку збудливості нервово-м'язового комплексу шляхом непрямого подразнення стимулами зростаючої інтенсивності від 1 П до 2 П з кроком 0,1 П. Явище рефрактерності аналізували шляхом непрямого подразнення пар- 
Огляди літератури, оригінальні дослідження, погляд на проблему

ними стимулами з інтервалом нанесення від 1 до 20 мс. Функціональну стійкість нервово-м'язового синапса вивчали із застосуванням серії з 10 імпульсів частотою від 50 до 500 Гц.

Дослідження проводили за допомогою стандартної електрофізіологічної апаратури (електростимулятор ЕСУ-2, підсилювач УБП 2-03, аналогово-цифровий перетворювач, персональний комп'ютер). Отримані результати оброблені за допомогою статистичних методів з визначенням середнього (M), помилки середнього (m), середньоквадратичного відхилення (б) для подальшого аналізу за критерієм Стьюдента з визначенням рівня достовірності (р).

Експерименти з лабораторними тваринами відповідали етичним вимогам Європейської кон- венції з використання хребетних тварин для експериментів. Евтаназію тварин після закінчення експерименту проводили шляхом введення летальної дози тіопенталу натрію.

Результати й обговорення. У тварин піддослідної групи величина порогового подразнення при непрямій стимуляції збільшилась на $(120,0 \pm 7,27)$ \% порівняно з контрольною групою, і дорівнювала $(0,055 \pm 0,004)$ мA $(p<0,01)$, наблизившись до значень цього показника у інтактних тварин [9]. Значення відповідних показників у контрольній групі в цьому та наступних випадках прийняті за 100 \%. Достовірні зміни хронаксії, латентного періоду, загальної тривалості та амплітуди викликаного ПД зафіксувати не вдалось (р>0,05, рис. 1).

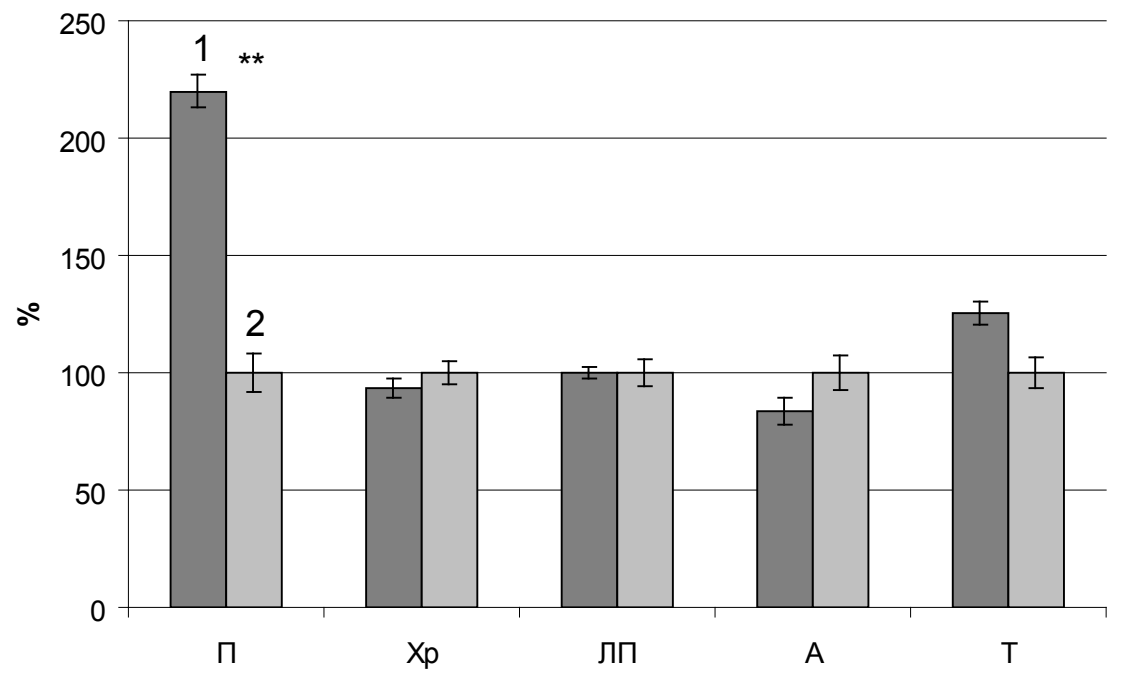

Рис. 1. Параметри збудливості нервово-м'язового комплексу та амплітудно-часові характеристики викликаного ПД за умов експериментальної менопаузи при застосуванні препарату Цитофлавін. 1 - піддослідна група, 2 - контроль. П- поріг, Хр - хронаксія, лП - латентний період, А- амплітуда, Т - тривалість. ** - p<0,01.

За умов прямого подразнення литкового м'яза також виявлено достовірне збільшення порогу збудження на $(85,71 \pm 6,15) \%(p<0,01)$, що дорівнювало $(0,13 \pm 0,008)$ мА та наближалося до значення у інтактних тварин $((0,17 \pm 0,03)$ мА) [9]. Хронаксія достовірних змін не зазнала (рис. 2).

При непрямому подразненні стимулами зі зростаючою інтенсивністю у піддослідній групі виявлено достовірне $(p<0,05)$ зменшення амплітуди відповіді на проміжку 1,2 П - 1,8 П (рис. 3), наближаючи профіль кривої залежності стимулвідповідь до інтактного [9].

При стимуляції сідничного нерва піддослідних тварин парними стимулами та пачками 3 10 імпульсів відмінностей, порівняно з контрольною групою, виявлено не було.

Нестача кисню, що визначає зниження його напруги в клітині, блокада дихального ланцюга і роз'єднання окисного фосфорилювання призводять до формування дефіциту АТФ (АДФ, АМФ) [3]. Це позначається на роботі їі енергозалежних систем, зокрема, 3NA $/ 2 \mathrm{~K}^{+}$АТФази зовнішньої клітинної мембрани [3]. У результаті відбувається зниження градієнта концентрації іонів по обидві сторони мембрани, що супроводжується посиленням виходу іонів $\mathrm{K}^{+} 3$ клітин, зниженням трансмембранного градієнта його концентрації і падінням мембранного потенціалу (спокою) [3], а отже, зниженням порогу збудливості нервової та м'язової тканин, що спостерігалось у наших попередніх дослідженнях $[9,10]$.

Рибофлавін забезпечує збереження і підтримання окиснювально-відновних реакцій, регульованих флавіновими коферментами. Як кофермент глутатіонредуктази, він відновлює пул глутатіону - найважливішого компонента антиоксидантної системи клітини [8]. Також він входить 
Огляди літератури, оригінальні дослідження, погляд на проблему

до складу дихальних ферментів мітохондрій, які здатні забезпечувати регенерацію НАД+[6]. Нікотинамід, як прекурсор коферментів дегідрогеназ (НАД+ і НАДФ ${ }^{+}$), є головним регуляторним механізмом ЦТК і частково - окисного фосфорилювання [6]. Бурштинова кислота прискорює обмін дикарбонової частини ЦТК (сукцинат - фумарат - малат) і знижує концентрацію лактату, що дуже важливо при її поєднанні з рибоксином. Наслідком є збільшення обсягу енергії, необхідної для синтезу АТФ і ГАМК. Бурштинова кислота збільшує споживання кисню тканинами і покращує тканинне дихання за рахунок посилення транспорту електронів в мітохондріях, відтворення протонного градієнта на їх мембранах і зміщення кривої дисоціації оксигемоглобіну вправо [11], а отже, підсилює віддачу кисню тканинам. [1].

Позитивні зрушення у енергопостачанні субклітинних структур під впливом антиоксидантних та антигіпоксантних компонентів препарату Цитофлавін можуть приводити до покращення роботи 3NA ${ }^{+} / 2 \mathrm{~K}^{+} \mathrm{AT}$ Фази та відновлення трансмем6ранного іонного градієнта з нормалізацією величини потенціалу спокою, а отже й збудливості. Свідченням цього $є$ збільшення порогу виникнення викликаних ПД як при прямому, так і при непрямому подразненні литкового м'яза (рис. 1, 2), а також нормалізація динаміки збудження, графічна крива якої наближається до показника інтактної групи тварин [9] (рис. 3).

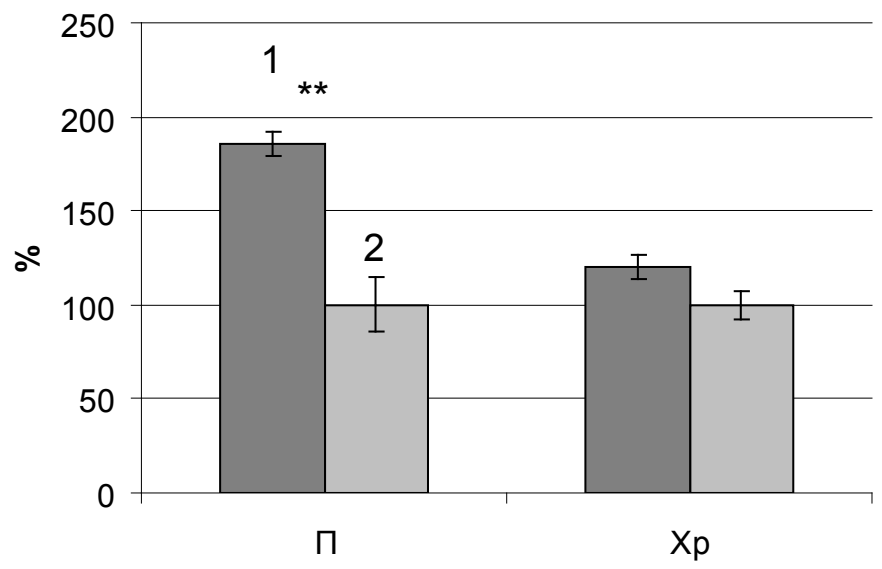

Рис. 2. Параметри збудливості литкового м'яза при прямому подразненні за умов експериментальної менопаузи при застосуванні препарату Цитофлавін. Позначення ті ж, що на рис. 1.

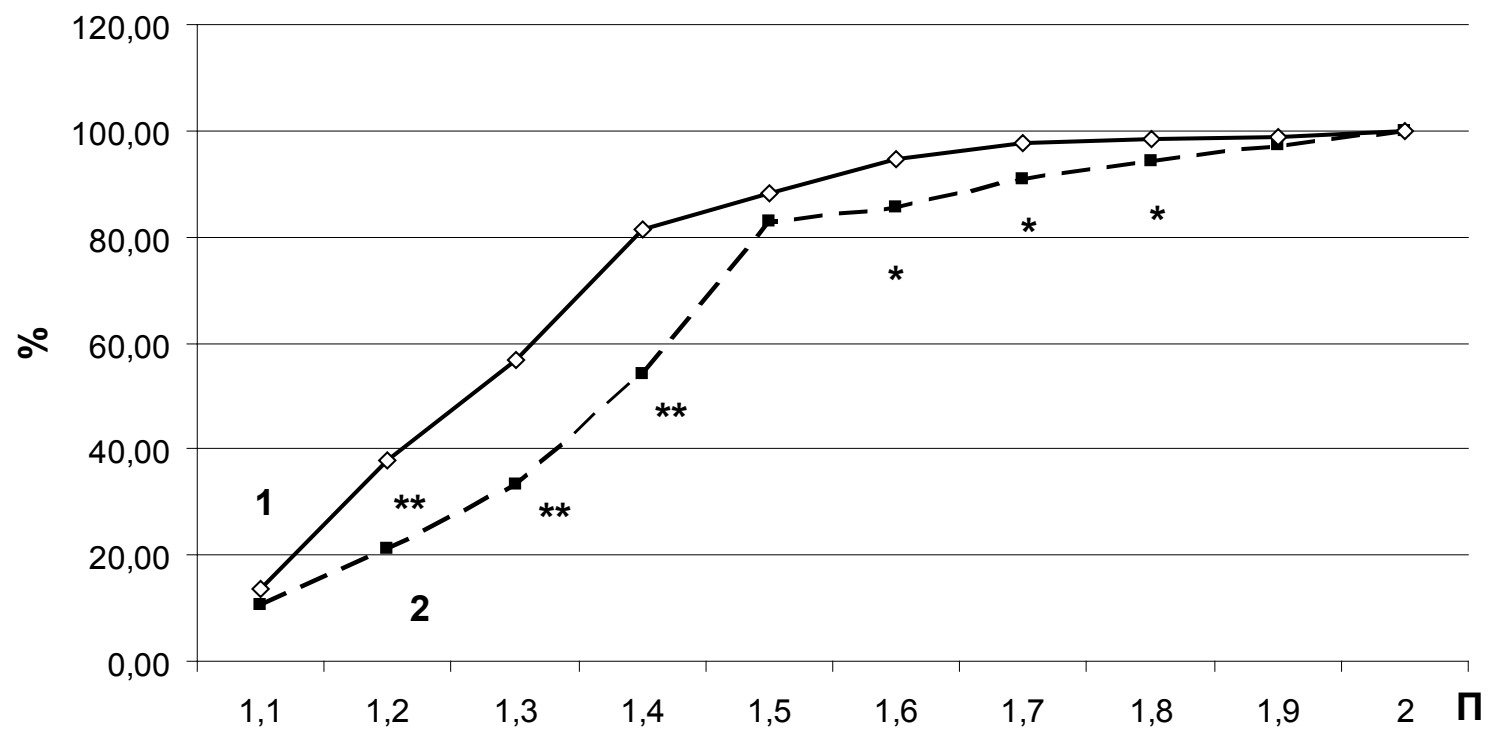

Рис. 3. Динаміка збудливості нервово-м'язового комплексу під дією Цитофлавіну за умов експериментальної менопаузи. Порівняння з контрольною та інтактною групами. 1 - контроль, 2 - інтактна група, 3 - піддослідна група. * - p<0,05; ** $-p<0,01$. 
Огляди літератури, оригінальні дослідження, погляд на проблему

Висновок. Під впливом компонентів препарату Цитофлавін, завдяки поліпшенню тканинного дихання, віддачі кисню гемоглобіном, звільненню цитоплазми від надлишкової концентрації недоокиснених метаболітів, покращенню синтезу макроергічних сполук (АТФ) на фоні зменшення кількості вільних радикалів створюються більш сприятливі умови для роботи іонних каналів, мембранних насосів нервових та м'язових клітин, що, у свою чергу, відображається на нормалізації

\section{ЛІТЕРАТУРА}

1. Афанасьев В. В. Цитофлавин в интенсивной терапии : пособие для врачей / В. В. Афанасьев. - СПб., 2005. -36 c.

2. Биличенко С. В. Антиоксидантная терапия сахарного диабета и его осложнений (экспериментальное исследование) : дис. на получение научн. степени канд. мед. наук: спец. 14.03.06 «Фармакология, клиническая фармакология" / С. В. Биличенко. - СПб., 2010. $113 \mathrm{c}$.

3. Владимиров Ю. А. Биологические мембраны и незапрограммированная гибель клетки / Ю. А. Владимиров // Соросовский образовательный журнал. 2000. - T. 6, № 9. - С. 2-9.

4. Доброхотова Ю. Е. Менопаузальный синдром / Ю. Е. Доброхотова // Лечебное дело. - 2004. - № 1. C. 3-8.

5. Клочева Е. Г. Применение препарата Цитофлавин в неврологии : [пособие для врачей] / Е. Г. Клочева. - СПб., 2008. -6 с.

6. Коваленко А. Л. Механизм действия и фармакокинетика метаболической композиции Цитофлавин / А. Л. Коваленко, А. Ю. Петров, М. Г. Романцов // Успехи современного естествознания. - 2002. - № 4. - С. 47-48.

7. Маличенко С. Б. Системные изменения в климактерии. Роль дефицита кальция и витамина D в формировании постменопаузального симптомокомплекса / С. Б. Маличенко, В. А. Волкова, К. К. Халидова // Современная ревматология. - 2008. - № 1. - С. 20-31.

8. Меньшикова Е. Б. Антиоксиданты и ингибиторы радикальных окислительных процессов / Е. Б. Меньшикова, И. К. Зенков // Успехи современной биологии. 1993. - Т. 113, № 4. - С. 442-455.

9. Родинський О. Г. Електрофізіологічний аналіз збудливості нервово-м'язового комплексу за умов експериментальної менопаузи / О. Г. Родинський, С. С. Ткаченко, О. В. Мозгунов // Експериментальна та клінічна фізіологія і біохімія. - 2014. - № 3. - С. 7-13. збудливості нервово-м'язового апарату. Отже, тестований препарат може бути рекомендований до застосування як один із компонентів комплексного лікування та профілактики віддалених нейропатичних ускладнень ранньої менопаузи.

Перспективи подальших досліджень. Перспективним $\epsilon$ дослідження впливу зазначеного препарату на викликану активність волокон сідничного нерва з метою уточнення механізму впливу на нервово-м'язовий комплекс.

10. Родинський О. Г. Моносинаптичні відповіді вентральних корінців спинного мозку в умовах експериментальної менопаузи / О. Г. Родинський, С. С. Ткаченко, Л. В. Гузь // Клінічна та експериментальна патологія. - 2015. - Т. 54, № 4. - С. 128-132.

11. Розенфельд А. Д. Регуляция сукцинатом вклада митохондрий в поддержание $\mathrm{pH}$ при АТФ-азных нагрузках : дис. на соискание ученой степени канд. биол. наук / А. С. Розенфельд. - Пущина, 1983. - 145 с.

12. Федотова Ю. О. Эффекты эстрогенов в центральной нервной системе / Ю. О. Федотова, Н. С. Сапронов // Успехи физиологических наук. - 2007. - Т. 38, № 2. - C. 46-52.

13. A new hypothesis about neuronal degeneration appeared after a rat model of menopause / D. Unal, Z. Halici, Z. Altunkaynak [et al.] // Neurodegener. Diseases. 2012. - Vol. 9, № 1. - P. 25-30.

14. Effects of acute changes in oestrogen on muscle function of the first dorsal interosseus muscle in humans / J. P. Greeves, N. T. Cable, M. J. Luckast [et al.] // J. Physiol. 1997. - Vol. 500, № 1. - P. 265-270

15. Effect of steroid hormones on the peripheral nervous system / M. Koszykowska, J. Wojtkiewicz, M. Majewski, B. Jana // J. Anim. Feed Sci. - 2008. - № 17. - P. 3-18.

16. N-myc downstream-regulated gene 2 , a novel estrogen-targeted gene, is involved in the regulation of $\mathrm{Na}^{+} / \mathrm{K}^{+}$-ATPase / Y. Li, J. Yang, S. Li [et al.] // J. Biol. Chem. 2011. - Vol. 286. - P. 32289-32299.

17. Paracrine and autocrine functions of neuronal vascular endothelial growth factor (VEGF) in the central nervous system / O. O. Ogunshola, A. Antic, M. J. Donoghue [et al.] // J. Biol. Chem. - 2002. - Vol. 277, № 13. P. $11410-11415$

18. Steroid hormone signaling between schwann cells and neurons regulates the rate of myelin synthesis / M. R. Paul, J. L. Andrew, K. N. Benjamin [et al.] // Ann. N. Y. Acad. Sci. - 2003. - Vol. 1007. - P. 340-348. 
Огляди літератури, оригінальні дослідження, погляд на проблему

\title{
IMPACT OF "CITOFLAVIN" ON BIOELECTRICAL ACTIVITY OF THE NEUROMUSCULAR COMPLEX IN CONDITION OF EXPERIMENTAL MENOPAUSE
}

\author{
๑O. H. Rodynskyi, S. S. Tkachenko, O. H. Zynovyeva
}

Dnipropetrovsk Medical Academy of Ministry of Health of Ukraine, Dnipropetrovsk

SUMMARY. The aim - experimental study of changes in bioelectric activity of the neuromuscular complex under the influence of the drug "Citoflavin» under experimental menopause. The drug was administered intraperitoneally to female white rats after 120 days ovariohysteroectoy for 10 days. There were analyzed the parameters of neuromuscular excitability complex parameters and responses caused by direct and indirect stimulation of the gastrocnemius muscle. There was significant $(p<0.01)$ increase in arousal threshold gastrocnemius muscle as the direct and indirect stimulation to $120.07 .27 \%$ and $85.71 \pm 6.15 \%$ respectively. Also, it was marked the decrease of the relative low threshold neuromotor units. Thus, under the influence of the drug Citoflavin, a normalization of excitability of the neuromuscular system under test and the drug can be recommended for use as a component of comprehensive treatment and prevention remote neuropathic complications of early menopause.

KEY WORDS: surgical menopause, neuromuscular complex, Citoflavin.

Отримано 5.04.2016 